\title{
Urban Heat Island and Park Cool Island Intensities in the Coastal City of Aracaju, North-Eastern Brazil
}

\author{
Max Anjos ${ }^{1,2, *}$ and António Lopes ${ }^{2}$ \\ 1 CAPES-Foundation, Ministry of Education of Brazil, Brasília DF 70040-020, Brazil \\ 2 IGOT-Instituto de Geografia e Ordenamento do Território/Centro de Estudos Geográficos, \\ Universidade de Lisboa, Ed. IGOT, Rua Branca Edmée Marques, 1600-276 Lisboa, Portugal; \\ antonio.lopes@campus.ul.pt \\ * Correspondence: maxanjos@campus.ul.pt; Tel.: +351-21-044-30-00
}

Received: 9 July 2017; Accepted: 2 August 2017; Published: 4 August 2017

\begin{abstract}
In this study, an evaluation of the Urban Heat Island (UHI) and Park Cool Island (PCI) intensities in Aracaju, North-Eastern Brazil, was performed. The basis of our evaluation is a 2-year dataset from the urban climatological network installed with the principles and concepts defined for urban areas related to climatic scales, sitting and exposure, urban morphology, and metadata. The current findings update UHI intensities in Aracaju refuting the trend registered in previous studies. On average, the UHI was more intense in the cool season $\left(1.3^{\circ} \mathrm{C}\right)$ than in hot season $\left(0.5^{\circ} \mathrm{C}\right)$, which was caused by wind speed decrease. In relation to the PCI, mitigation of high air temperatures of $1.5-2{ }^{\circ} \mathrm{C}$ on average was registered in the city. However, the urban park is not always cooler than the surrounding built environment. Consistent long-term monitoring in the cities is very important to provide more accurate climatic information about the UHI and PCI to be applied in urban planning properly, e.g., to provide pleasant thermal comfort in urban spaces.
\end{abstract}

Keywords: Urban Heat Island; Park Cool Island; urban climatological network; urban climate; North-Eastern Brazil; Aracaju

\section{Introduction}

The Urban Heat Island (UHI) is one of the most well-known thermal patterns in settlements. In recent decades, the need to investigate this phenomenon in greater depth has been increasing due to its countless impacts on society and the urban environment. The UHI refers to the generally warmer urban atmosphere when compared with the surrounding non-urban areas. More commonly, $\mathrm{UHI}$ intensity is defined as the maximum temperature difference between urban and rural areas $\left(\Delta \mathrm{Tu}_{=\text {urban }} \mathrm{r}_{\text {rural }}\right)$. There are two main approaches to UHI-each one with advantages and disadvantages. The first approach ( $\Delta$ Tu-r) compares the temperature of the warmest location in the urban area with the temperature of a location in the rural area that is seen as the coolest. Brazilian cities are characterized by complex urban morphologies, and therefore defining what is actually 'urban' and 'rural' is not an easy task [1], since those adjectives may have different connotations. Consequently, there may be urban areas that are not the warmest, and thus the heating of non-urban areas cannot be disregarded from the analysis.

Although $\Delta$ Tu-r has shown promise in the absence of an urban monitoring network and when there are limited resources, its spatial resolution is restricted to measuring sites which do not convey the land use complexity. UHI studies that typically use fixed sensors are restricted to a limited time period (a few days, weeks, or months), whereas when analyzing long-term series the use of automatic or conventional weather stations is better suited to represent the regional climate instead of the local one [2]. 
In this paper, we make a substantial distinction between local climate and UHI. Although both are directly related, they differ fundamentally in terms of their scale of analysis. While the local climate is a succession of microclimates, the UHI is a succession of local climates in the urban areas, in comparison to the ones in the rural areas or the non-urban surroundings. When we compare, for example, a station located in a specific neighborhood or in a valley with a station in a rural area what is actually being done is comparing the thermal difference between two local climates. To reach the $\Delta \mathrm{Tu}_{\text {(group) }}{ }^{-\mathrm{r}}$ (group) of the UHI, we need to minimize the microclimatic influences of each station so that the local influence prevails. Some studies have used a group of stations to calculate UHI intensity instead of using only one station that represents the urban area and another that represents the rural area [3-5].

The second most commonly used approach as an indicative of the UHI intensity is the temperature measurement along a transect of different land uses using a mobile platform. The mobile transect has the compensatory advantage of having a high spacial resolution of the measurements, but this technique has a limited time scale of usually a few hours a day. The days chosen for the measurements are generally related with weather conditions (clear skies and light winds), when thermal contrasts are expected to show with particular clarity [6-8]. However, these 'ideal' weather conditions only happen once in a while, which results in a limited representation, which in turn leads to narrow interpretations or simplistic generalizations about UHI intensity. Morris et al. [5] alerted to the fact that many UHI studies have been restricted to atypical weather conditions, usually sampled over a limited time period.

A near universal finding is that the intensity of a UHI at a given place is greatest at night (and $4 \mathrm{~h}$ after sunset) when the synoptic conditions can be characterized by high pressure, clear skies, little wind, and no precipitation, as pointed out by Alexander and Mills [9]. However, if the UHI is consistently under long-term monitoring, results may point to the fact that the temperature difference between the urban and the surrounding areas is more complex. By using daily data between 1972 and 1991, Morris et al. [5] showed, among other results, that the variation in the amount of clouds from 0 to 8 octas had very little influence on Melbourne UHI when the mean wind was $\geq 5 \mathrm{~ms}^{-1}$. By using daily data between 2004 and 2012, Lopes et al. [3] and Alcoforado et al. [4] reported that low wind speeds were not associated with the highest Lisbon UHI intensities. In Aracaju, using the approaches discussed above, some studies pointed to higher heating in the central areas (up to $7.5^{\circ} \mathrm{C}$ ) in relation to the peri-urban areas and green spaces, which suggests that UHI intensities are equally significant [10-12]. Anjos and Lopes [13] used a mesoscale climatological network (2 year daily data) to report that UHI intensities (both daytime and nighttime) in Aracaju were not significant (average of $0.5^{\circ} \mathrm{C}$ ) reflecting the prevalence of low intensities (thermal difference up to $2{ }^{\circ} \mathrm{C}$ ) whose frequencies exceeded $85 \%$ annually thus refuting the trend found in previous studies.

Therefore, the spacial and time limitations of the $\Delta$ Tu-r and mobile transect approaches can increase inconsistencies in the conceptual model or the nature of the UHI [14], or they can lead to the widespread idea in the literature that temperature differences within the city are enough to explain the UHI [15]. A dense climatological monitoring offers an opportunity to better understand UHI intensity because it provides continuous climatological data in mesoscales local and microclimatic scales of different places within city. Also, long-term monitoring supports a better appreciation of the climatic influences related to land use complexity, including the different range of weather conditions in the region. Besides, dense climatological monitoring allows a deeper study of the phenomena associated with UHI, such as the Park Cool Island (PCI).

$\mathrm{PCI}$ considers the role of the vegetation by radiative exchanges and evaporative cooling processes between the shaded surface and the adjacent surface [16], which, among other ecosystemic benefits, helps to mitigate UHI effects [17]. In different climatic contexts, many studies have highlighted the role played by green spaces in temperature reduction [18-20]. Even a small urban park (0.24 ha) can significantly influence the urban environment with a temperature decrease of up to $7^{\circ} \mathrm{C}$ [17], and a single tree has the ability to improve the feeling of thermal comfort in relation to the immediate surroundings [18]. 
However, the combination of factors such as size, type, the composition of the species, geographic factors, and meteorological variables influences the potential green space effect on temperature $[19,20]$. This combination can lead to an unwanted climatic effect that is warmer than the surrounding areas. In Tel Aviv, Israel, Potchter et al. [21] observed that parks with grass and few trees were warmer than built-up areas. Analyzing 61 parks in Taipei, Taiwan, Chang et al. [22] showed that approximately one-fifth of them were warmer than their urban surroundings, and in summer, at noon, parks with $\geq 50 \%$ paved coverage and few trees and shrubs were on average warmer than their surroundings. These authors concluded that large parks were on average cooler than the smaller ones, but this relationship was non-linear. In Mexico City, Jauregui [23] reported that on sunny mornings the park heats up more slowly than the built-up area and two hours after midday there was not a significant difference in temperature between the park and surroundings. Thus, real-time climatological monitoring of the PCI is critical to understand the beneficial function of green spaces in the city as well as to assess the potential of any unwanted climatic features.

As part of an ongoing engagement with the climatic guidelines for the urban planning of Aracaju, this paper aims at assessing the UHI and PCI effects based on an urban climatological network.

\section{Materials and Methods}

\subsection{Study Area and Urban Climatological Network}

Aracaju is situated on the northeast coast of Brazil with more than 600 thousand inhabitants living in an area of $181.8 \mathrm{~km}^{2}$, whose population density is of 3 thousand people per $\mathrm{km}^{2}$. The city is delimited by the following coordinates: $10^{\circ} 51^{\prime}$ and $11^{\circ} 07^{\prime} \mathrm{S}, 37^{\circ} 02^{\prime}$ and $37^{\circ} 09^{\prime} \mathrm{W}$ (Figure 1). It is located fully in the intertropical zone, which is responsible for its climatic characteristics of hot summers and cool winters. The latitudinal and coastal positions expose Aracaju to several macro and mesoscale systems (e.g., east and southeast trade winds and the sea breeze system), which largely explain the weather and climate conditions in the city. Aracaju's climate is tropical and humid, corresponding to type $A m$ in the Köppen climatic classification. The city has average temperatures of $27^{\circ} \mathrm{C}$, with rainfall above $1300 \mathrm{~mm}$, relative humidity around $70 \%$, and high levels of daily solar insolation with an average of $5 \mathrm{kWh} \mathrm{m}^{-2}$ day $^{-1}$ throughout the year, which is regarded as a naturally 'stressful' thermal environment.

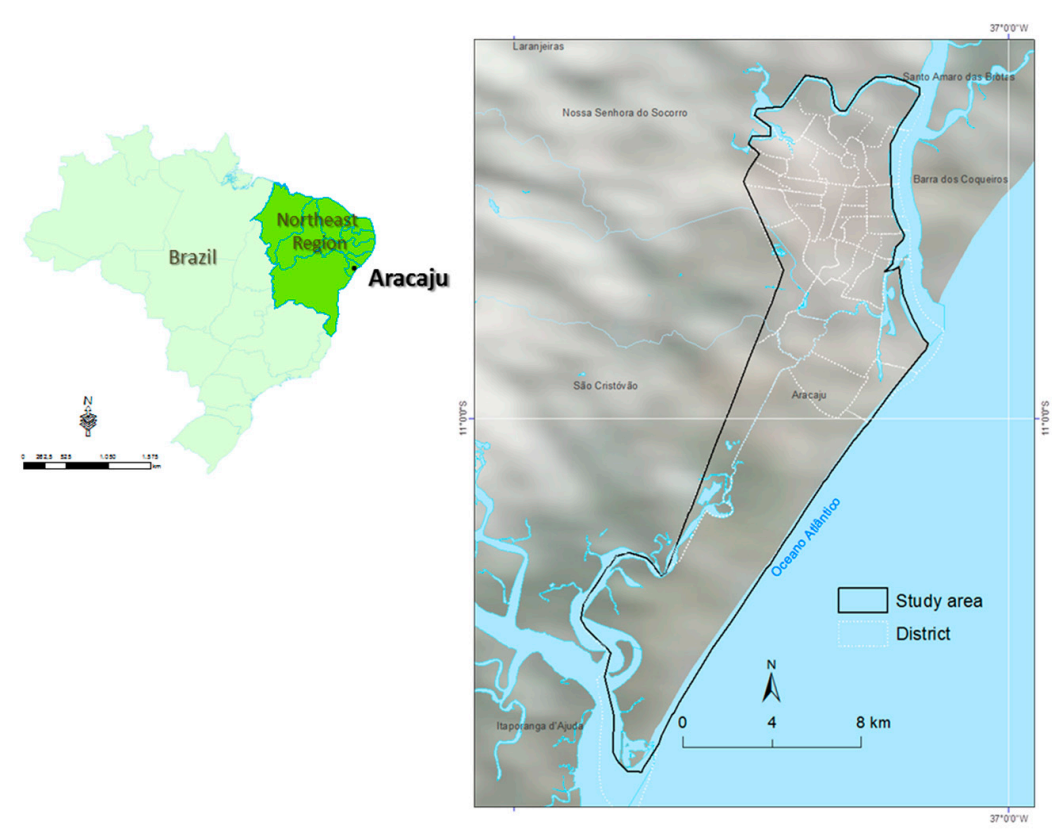

Figure 1. Geographic location of the study area. 
The Urban Climatological Network (UCN) observed principles and concepts defined for urban areas, particularly concerning matters that relate to climatic scales, site and exposure [8], metadata [24], local urban morphology, and Local Climate Zones (LCZ). LCZ are defined as regions of uniform surface cover, structure, material, and human activity that span hundreds of meters to several kilometers in the horizontal scale [25]. Aracaju LCZ map was created within the WUDAPT project [26] using a simple method that uses Landsat8 satellite images and software (SAGA), easily accessible by anyone [27] (for more information see http:/ /www.wudapt.org/) (Figure 2).

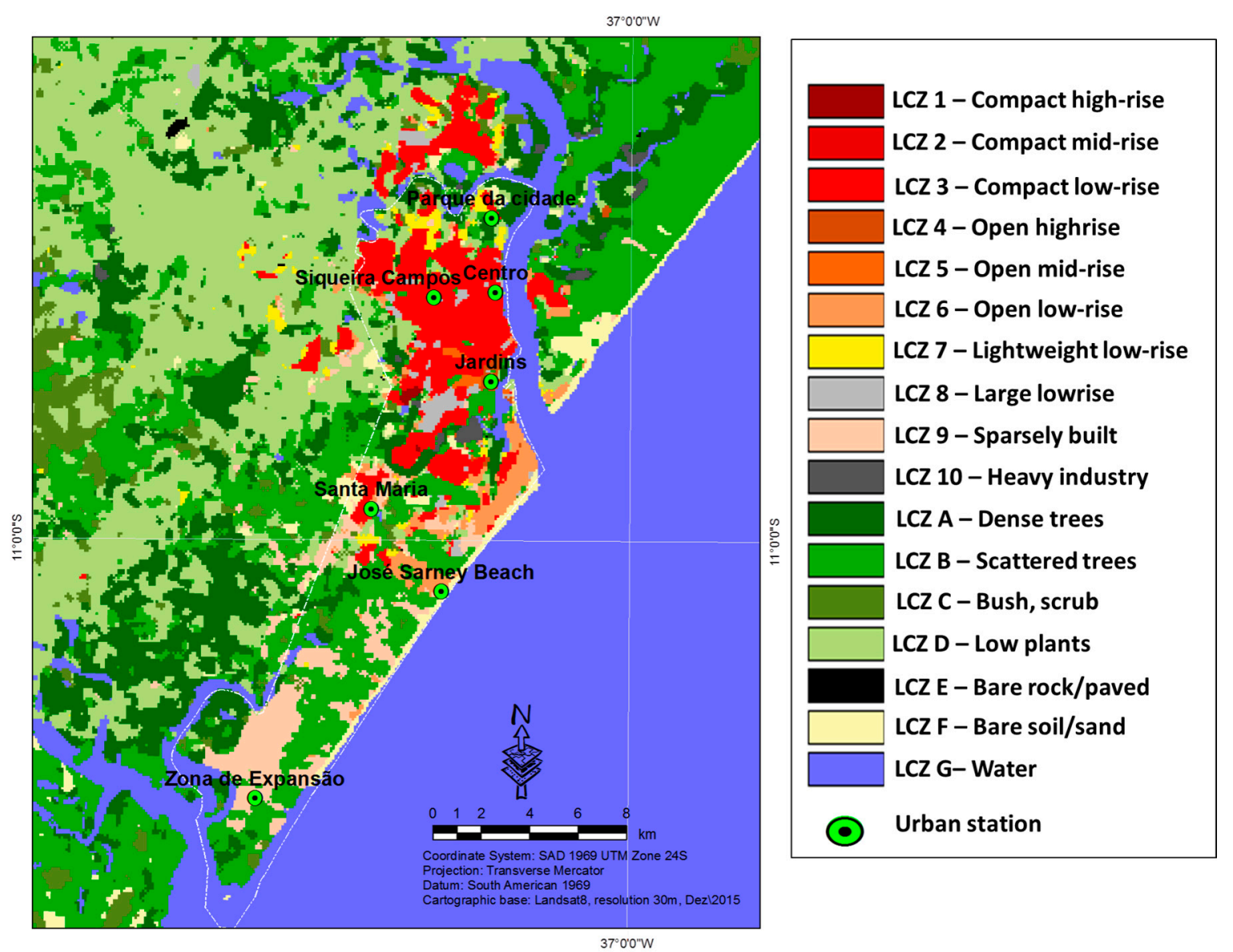

Figure 2. Aracaju local climate zone map and urban stations' locations.

Once the LCZ were defined, the measuring sites were selected. Seven HOBO U23 Pro v2 Temperature/Relative Humidity Data Logger U23-001 by Onset Computer Corporation ${ }^{\circledR}$ (Bourne, MA, USA) sensors were used (Figure 3). Every sensor is indicated as an urban station and located on lamp-posts at $3.5 \mathrm{~m}$ above ground to record the processes of heating and cooling exchanges which occur below the rooftops in the spaces between buildings, i.e., the so-called Urban Canopy Layer [8]. The urban stations were placed in a thermal source area (circle of influence) with a $500 \mathrm{~m}$ radius around the sensor where air temperature could be representative of the LCZ. Positioning urban stations in the city took in account the shading and sheltering effects of buildings and trees; ensuring the measurement sites in an open space (Sky View Factor > 0.70). The location and urban features of each measurement site are illustrated in Figure 3 and Table 1. 


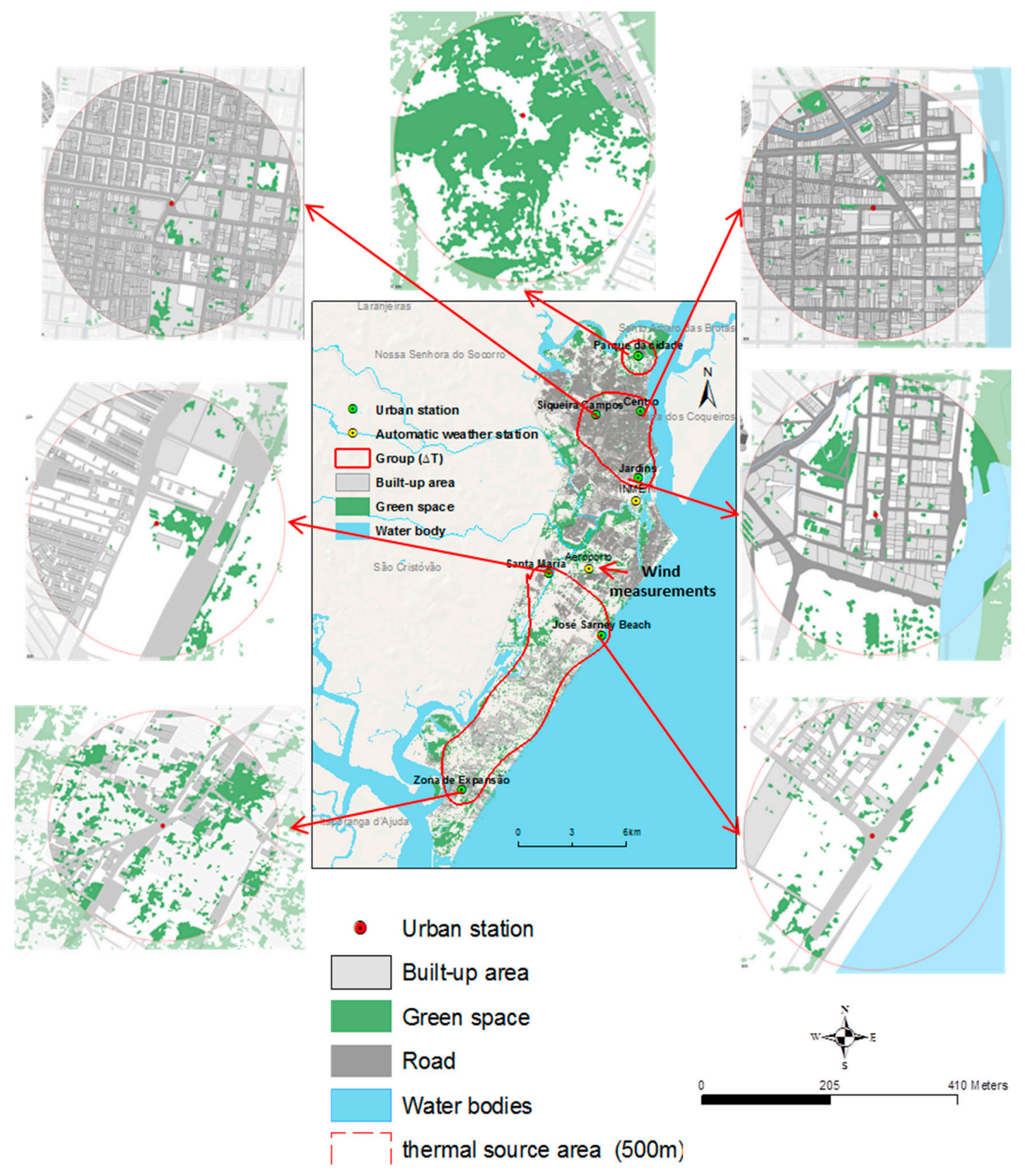

Figure 3. Urban Climatological Network in Aracaju.

Table 1. Description of the urban stations and the Local Climate Zones (LCZ).

\begin{tabular}{|c|c|c|c|c|c|c|}
\hline \multirow{2}{*}{$\begin{array}{l}\text { Urban Station } \\
\text { (Sensor) }\end{array}$} & \multirow[b]{2}{*}{ LCZ Types } & \multicolumn{5}{|c|}{ Local Scale $\left(>1 \mathrm{~km}^{2}\right)^{1}$} \\
\hline & & SVF (0 to 1) & $\begin{array}{l}\text { Built-Up } \\
\text { Area (\%) }\end{array}$ & $\begin{array}{l}\text { Impervious } \\
\text { Surface }(\%)\end{array}$ & $\begin{array}{l}\text { Vegetated } \\
\text { Area }(\%)\end{array}$ & $\begin{array}{c}\text { Water } \\
\text { Bodies (\%) }\end{array}$ \\
\hline Siqueira Campos & Compact low-rise (LCZ 3) & 0.808 & 76.6 & 96 & 3.4 & 0 \\
\hline Centro da Cidade & Compact low-rise (LCZ 3) & 0.708 & 69.3 & 93 & 2.2 & 0 \\
\hline Jardins & Open high-rise (LCZ 4) & 0.768 & 66.5 & 70.7 & 12.4 & 6.4 \\
\hline Parque da Cidade & Dense trees (LCZ A) & 0.948 & 5.5 & 7.5 & 53 & 0 \\
\hline Santa Maria & Lightweight low-rise (LCZ 7) & 0.953 & 23 & 49.3 & 9.4 & 0 \\
\hline José Sarney Beach & Open low-rise (LCZ 6) & 0.965 & 12.4 & 23.6 & 6 & 50 \\
\hline Zona de Expansão & Sparsely built (LCZ 9) & 0.981 & 21 & 30.5 & 24 & 0 \\
\hline
\end{tabular}

${ }^{1}$ Measured within a $500 \mathrm{~m}$ square centered over the measuring sites in the canopy layer. 


\subsection{Dataset Used}

From the UCN data set, hourly temperature was used to assess UHI and PCI intensities, consisting in 19,640 cases from 19 July to 10 October (henceforth referred to as the 2014-2016 period). For this period, hourly data of wind speed and cloudiness were used because the development of the UHI is influenced by the mixture of turbulence and air advection, and radiative exchanges. The data from the Santa Maria Airport station (Cod. SBAR) located in the peri-urban area of the city is less exposed to the influence of urban factors. Six categories of wind speed stratification were defined: $0<x \leq 2$ $\mathrm{ms}^{-1} ; 2<\mathrm{x} \leq 4 \mathrm{~ms}^{-1} ; 4<\mathrm{x} \leq 6 \mathrm{~ms}^{-1} ; 6<\mathrm{x} \leq 8 \mathrm{~ms}^{-1} ; 8<\mathrm{x} \leq 10 \mathrm{~ms}^{-1} ; \mathrm{x}>10 \mathrm{~ms}^{-1}$. Sky condition is described as the appearance of cloud coverage observed by the weather station. Four types of sky conditions were defined: clear sky ( 0 octas); partly cloudy (from $1 / 8$ to 4 / 8 octas); very cloudy (from $5 / 8$ to $7 / 8$ octas); overcast sky ( 8 octas). To ensure a correct assessment of the variability of both space and time, a quality control procedure was performed to validate the internal coherence in the analyzed series (e.g., unreal value). Then, the stratification of wind speed and cloudiness was related to UHI and PCI intensities.

\subsection{Defining UHI and PCI Intensities}

The architecture of the UCN assessed objectively the intensity of the UHI in Aracaju. A cluster analysis algorithm was used to cluster the hourly data temperatures according to their similarities. Thus, it was possible to find groups of thermal similarities between the urban stations, taking into account the presence of green spaces, urban densities, water bodies, and ventilation. Considering the proprieties in the Table 1, the urban stations were divided into three groups up to level 4 (linkage distance), as defined in the dendrogram in Figure 4. Thus, group 1 comprises the central urban stations (Jardins, Centro da Cidade, and Siqueira Campos) characterized by relative high and medium urban densities (built up area varying between 60 and $70 \%$, impervious surface over $70 \%$ and vegetated area up to 12\%), group 2 the peri-urban stations (Zona de Expansão, Santa Maria, and José Sarney Beach) characterized by low urban densities (built up area varying between 12 and 23\%, impervious surface $23-49 \%$ and vegetated area 6-24\%) and greater oceanic influence (50 of water bodies), and group 3 the Parque da Cidade representing the green space influence (53\% of the area has vegetation) (Figure 3).

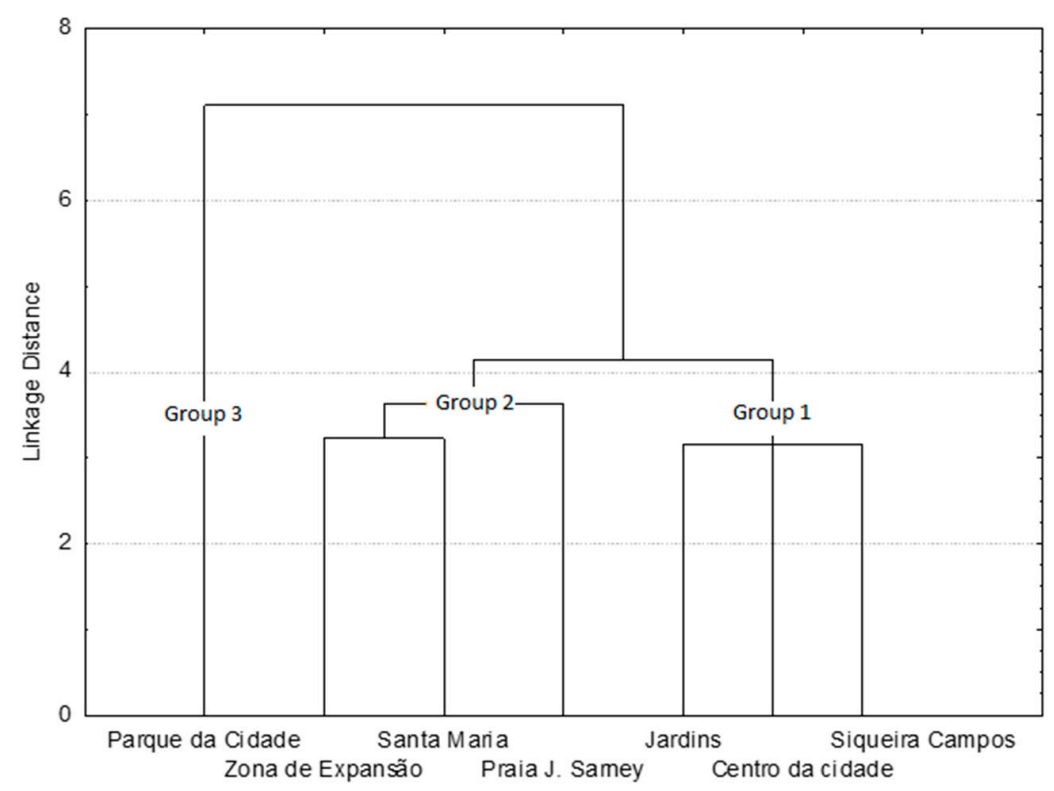

Figure 4. Similar temperature groups (hourly data) between the urban stations in the 2014-2016 period (adapted from Anjos and Lopes [28]). 
After the groups of thermal similarity were defined, the calculation of UHI intensity (UHII) was carried out, taking into consideration criteria, such as the occurrence, in a specific moment, of temperatures in the center of the city that were higher than temperatures in peri-urban areas, using the following equation $[3,4]$ :

$$
\mathrm{UHII}=\mathrm{T}_{\mathrm{ur}}\left(\mathrm{T}_{\max }\right)-\mathrm{T}_{\mathrm{pr}}\left(\mathrm{T}_{\min }\right)
$$

where, $\mathrm{T}_{\text {ur }}$ corresponds to the hourly maximum temperature of three measuring sites in the center of the city (group 1) and $\mathrm{T}_{\mathrm{pr}}$ the minimum hourly temperature of three measuring sites in peri-urban areas (group 2). The thermal averages were used together to avoid the possibility that the microclimatic influence of each urban station should prevail over the local scale, as discussed in the introduction to this paper.

By the same reasoning, the PCI intensity (PCII) was calculated, using the following equation:

$$
\mathrm{PCII}=\mathrm{T}_{\mathrm{ur}}\left(\mathrm{T}_{\max }\right)-\mathrm{T}_{\mathrm{pc}}\left(\mathrm{T}_{\min }\right)
$$

where, $\mathrm{T}_{\mathrm{pc}}$ is the minimum hourly temperature in the Parque da Cidade (Group 3).

To examine the seasonal and daily effect of the UHII and PCII, the hourly data were divided into seasons and daytime and nighttime periods [3,29]. The knowledge of local climatology [12] reveals hot summers and cool winters. Considering the 1961-1990 Climate Normals, June and September show the largest number of occurrences of low monthly temperatures $\left(22-23^{\circ} \mathrm{C}\right)$ and, therefore, this period was defined as the 'cool season', whereas the remaining months $\left(24-25^{\circ} \mathrm{C}\right)$ (October-March) were defined as the 'hot season'. To determine the hours that correspond to the daytime period (from 10:00 to 20:00) and nighttime (from 22:00 to 07:00), the SOLWEIG software [30] was used. The transition hours between sunrise and sunset were excluded to avoid microclimatic influence on the sensor of buildings or nearby trees.

The stratification of the UHI intensity, based on García [31], was defined as follows: low intensity, when the thermal differences are up to $2{ }^{\circ} \mathrm{C}$; medium intensity, when these are between 2 and $4{ }^{\circ} \mathrm{C}$; and strong intensity, when above $4{ }^{\circ} \mathrm{C}$. The same classification was used to assess PCI intensity, according to the following reasoning: the strongest PCII means higher temperature reduction due to the influence of green spaces (cooling effect) in relation to the surrounding areas.

\section{Results}

\subsection{Intraurban Temperatures Sasonal Variation (Hourly Means)}

Seasonal hourly average temperature variation between the urban stations for the 2014-2016 period is illustrated in Figure 5. From nighttime and part of the morning in the hot seasonal (23:00-09:00), two sites presented the major thermal differences, Jardins was hotter at around $28^{\circ} \mathrm{C}$ and Parque da Cidade was cooler with minimum temperature of $25^{\circ} \mathrm{C}$ (at 09:00). However, during hot afternoons, there is an unexpected rise in average temperature in Parque da Cidade. It recorded the highest temperature $\left(30^{\circ} \mathrm{C}\right.$ at 15:00) of the analyzed urban stations. In contrast, José Sarney Beach recorded the lowest mean temperature during hot afternoons, showing the influence of the ocean. In the cool season, the thermal difference between the urban stations became clear, i.e., the central city sites were hotter during the entire diurnal cycle. Jardins, Centro da Cidade, and Siqueira Campos recorded the highest mean temperatures of $29.5^{\circ} \mathrm{C}, 29^{\circ} \mathrm{C}$, and $28.7^{\circ} \mathrm{C}$ at $16: 00$, respectively, in contrast to peri-urban sites (Santa Maria and Zona de Expansão both with $28^{\circ} \mathrm{C}$ ) incluing Parque da Cidade and José Sarney Beach with the lowest mean temperature values $\left(27^{\circ} \mathrm{C}\right)$. 


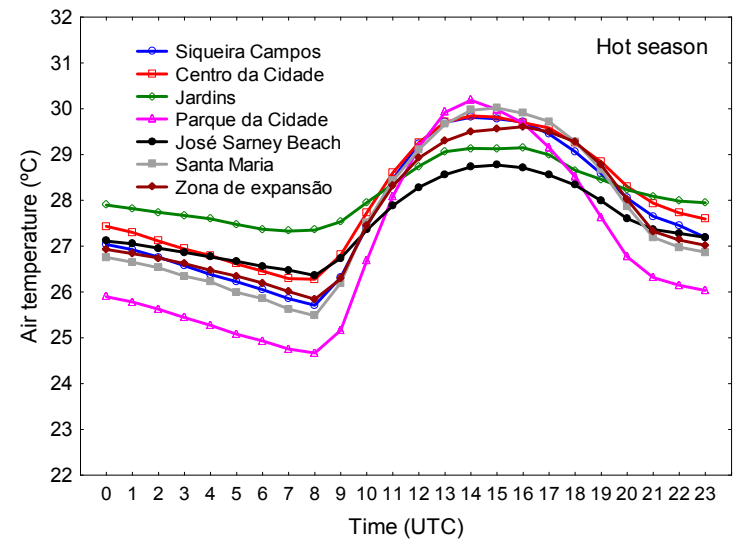

(a)

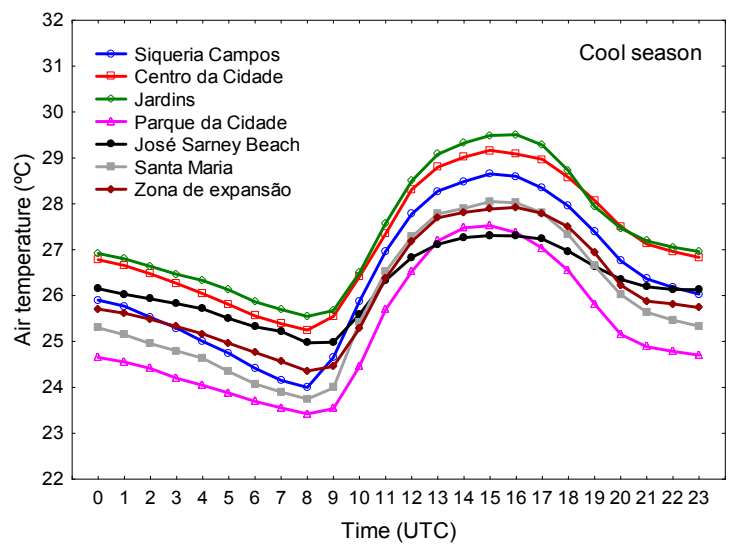

(b)

Figure 5. Daytime variation of the hourly mean temperatures for seven urban stations in the (a) hot season and (b) cool season in the 2014-2016 period.

\subsection{UHI and PCI Intensity Statistics}

\subsubsection{Summary of the Data Series}

As can be seen in Figure 6, the complete summary of UHI and PCI intensities in the 2014-2016 period shows that both daytime and nighttime UHII remained steady and reached less than $1{ }^{\circ} \mathrm{C}$ in $25 \%$ to $74 \%$ of the cases. UHII reached the maximum extremes of $5.5{ }^{\circ} \mathrm{C}$ and minimum of $-3.3{ }^{\circ} \mathrm{C}$ during daytime and maximum of $3.5^{\circ} \mathrm{C}$ and minimum of $-2{ }^{\circ} \mathrm{C}$ during nighttime. The average and median PCI intensity varied by around $2{ }^{\circ} \mathrm{C}$ in $25 \%$ to $74 \%$ of the observations, and the maximum intensity of $6.6^{\circ} \mathrm{C}$ and minimum of $-2.6{ }^{\circ} \mathrm{C}$ during daytime, and $4{ }^{\circ} \mathrm{C}$ and $-1{ }^{\circ} \mathrm{C}$ during nighttime were recorded.

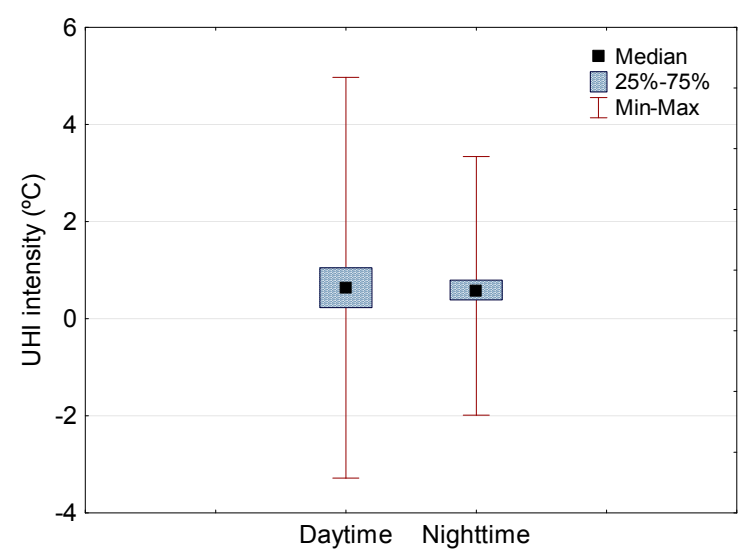

(a)

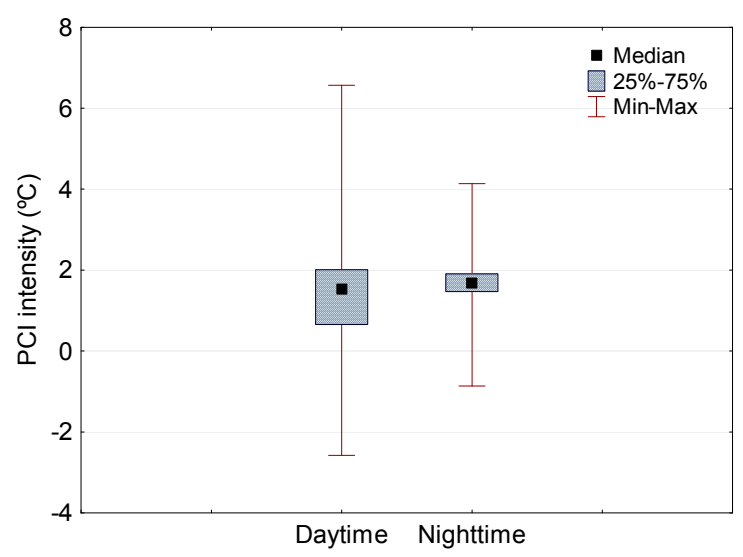

(b)

Figure 6. Summary of the complete series of the Urban Heat Island (UHI) (a) and Park Cool Island (PCI) (b) intensities in the 2014-2016 period.

\subsubsection{Daily Seasonal Relative Frequencies}

Figure 7 plotted the daily relative UHII and PCII seasonal frequencies for the period of study. In the hot season, the highest frequencies of the UHII ( $>87 \%$ ) occurred invariably in the lower intensity class (thermal difference of up to $2{ }^{\circ} \mathrm{C}$ ) in both daytime (hot days) and nighttime (hot nights). The average intensity UHI class $\left(2{ }^{\circ} \mathrm{C}\right.$ to $\left.4{ }^{\circ} \mathrm{C}\right)$ recorded frequencies of $2 \%$ during daytime, whereas it did not occur in hot nights. The strong intensity UHI class $\left(>4^{\circ} \mathrm{C}\right)$ did not occur on either daily hot 
season analyzed. In the cool season, the low intensity UHI frequencies remained steady with less than $80 \%$. However, UHII appeared in the average intensity with almost $20 \%$. Strong intensity of UHI $\left(>4{ }^{\circ} \mathrm{C}\right)$ also did not occur in any moment of that season. These results suggested that there is no clear distinction between day or night in terms of UHI. Regarding relative frequencies of the PCI, Figure 7 shows that the low intensity class was more prevailing (between $50 \%$ and $90 \%$ ) in both seasons and daily. Remember this means that the temperature reduction due to the influence of green spaces was up to $2{ }^{\circ} \mathrm{C}$. The average intensity PCI class was more significant in the cool season, varying between $22 \%$ on cool days and $45 \%$ on cool nights compared with $12 \%$ on hot days and $7 \%$ on hot nights. The strong intensity PCI class $\left(>4{ }^{\circ} \mathrm{C}\right)$ occurred only $2 \%$ during cool days.

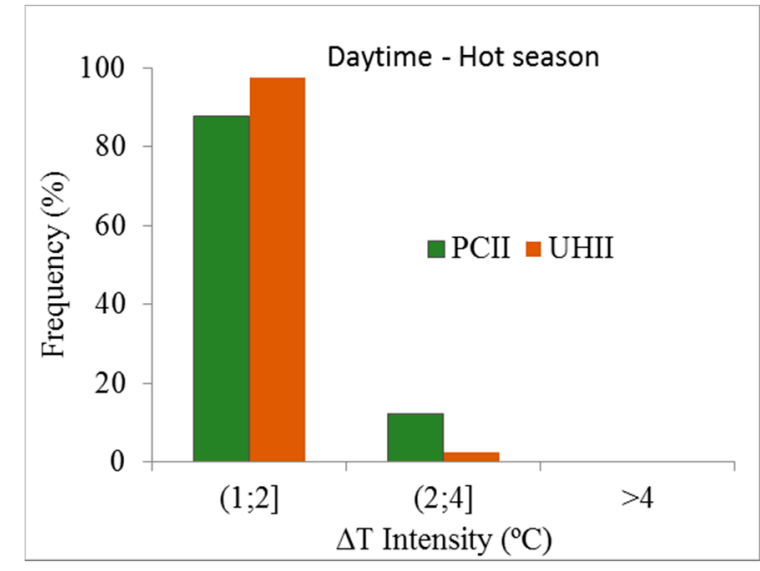

(a)

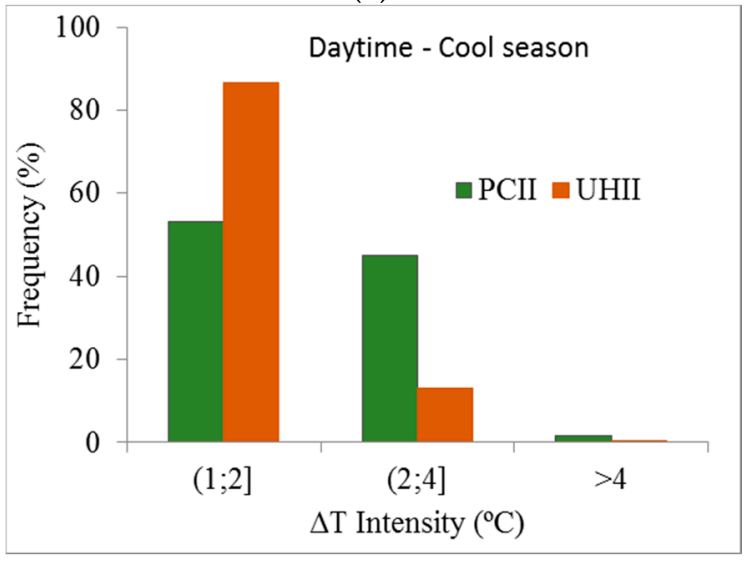

(c)

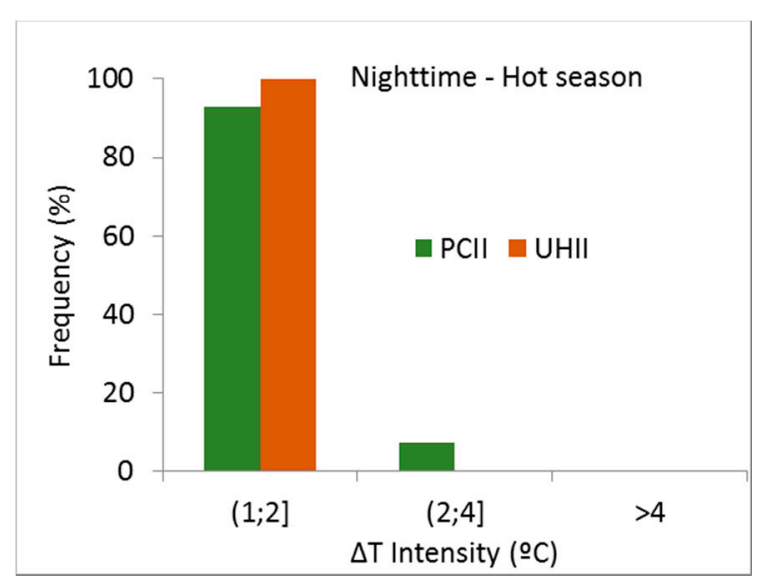

(b)

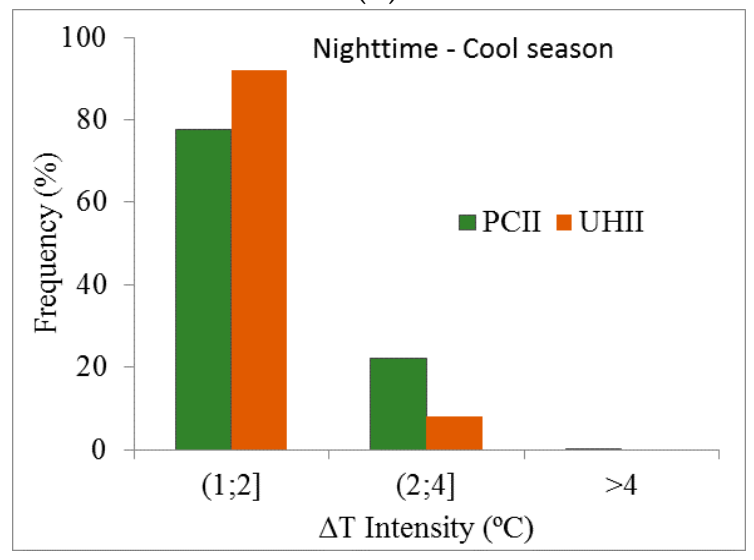

(d)

Figure 7. Daily relative frequencies of UHI and PCI intensities in the hot season $(\mathbf{a}, \mathbf{b})$ and in the cool season $(\mathbf{c}, \mathbf{d})$.

\subsubsection{Number of Observations of UHI and PCI Intensities Equal to or Greater Than $2{ }^{\circ} \mathrm{C}$}

Significant UHI and PCI intensities, which takes into account the total number of observations that are equal to or greater than $2{ }^{\circ} \mathrm{C}$ was computed (Figure 8). In most of the observations (435), the UHII $\geq 2{ }^{\circ} \mathrm{C}$ occurred between 09:00 and 18:00 (out of 15,640 total). Comparing with the UHII, the PCIII $\geq 2{ }^{\circ} \mathrm{C}$ with the total of 3774 cases was more significant, with a steep increase at night and in the morning (20:00-11:00), with a peak of 285 observations at 10:00. The number of observations of the PCII $\geq 2{ }^{\circ} \mathrm{C}$ declined in the period from 12:00 to 19:00 with a minimum of 88 cases (Figure 8). 


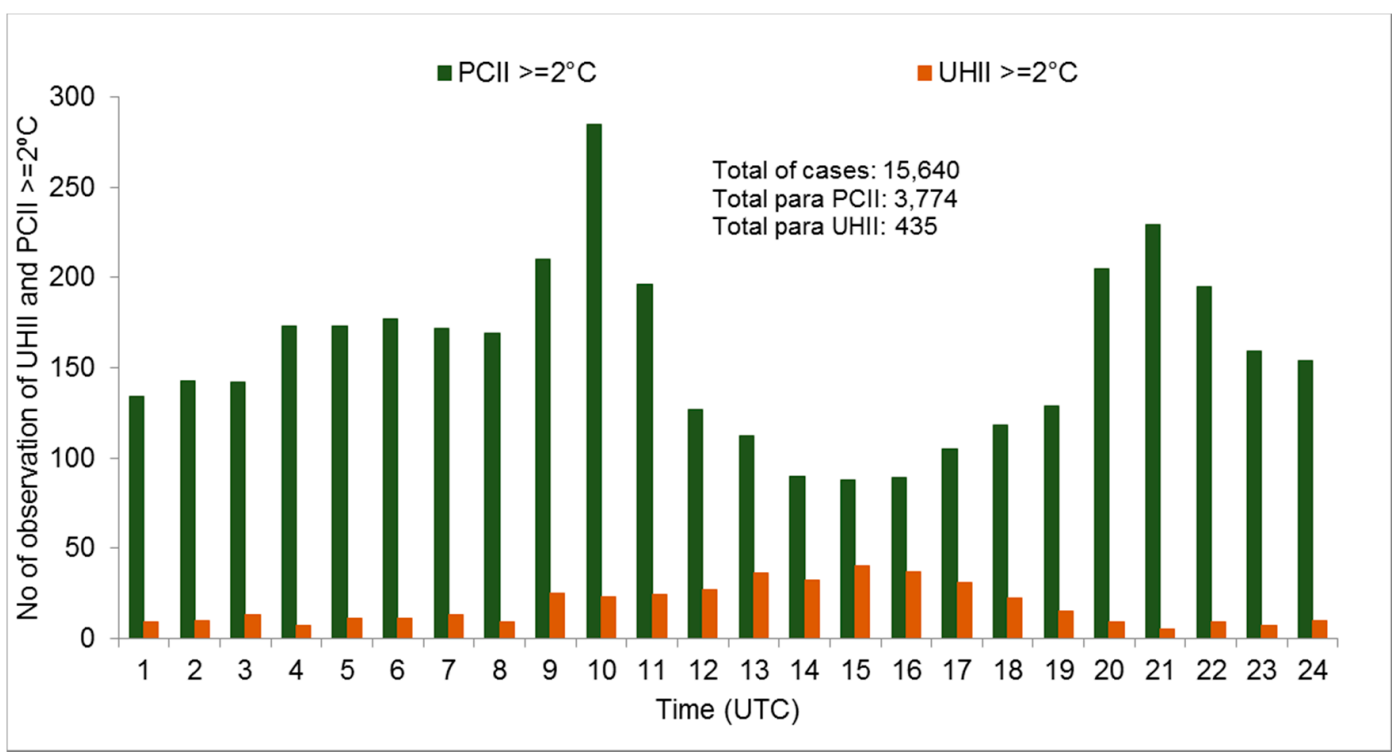

Figure 8. Number of observations of UHI and PCI intensities $\geq 2{ }^{\circ} \mathrm{C}$ in the $2014-2016$ period.

\subsection{The Relationship Between UHII and PCII and Wind Speed}

Daily variation of UHI intensity in Aracaju and its relationship with the wind speed pattern is indicated in Figure 9a,b. In the hot season, there was a steady fluctuation of the average UHI intensity throughout the day of around $0.5^{\circ} \mathrm{C}$, which indicates a slight warming of the central areas when compared to peri-urban areas. As expected, PCI intensity was more significant than UHI intensity with the average peak of $2{ }^{\circ} \mathrm{C}$ and average values remained steady around $1.7^{\circ} \mathrm{C}$ from night until the morning (20:00-09:00). This relates to the fact that during the afternoon the PCI intensity values declined abruptly below $1{ }^{\circ} \mathrm{C}$ at 15:00, when there was an increase of the average wind speed, which indicates a reduction difference temperature of the central areas when compared to urban park (Figure 9a). In the cool season, however, the average UHI intensities increased starting at 10:00 with a peak of $1.3{ }^{\circ} \mathrm{C}$ at $15: 00$, when there was a decrease of the overall average wind speeds compared to other the season in Figure $9 \mathrm{~b}$. In this wind speed situation, the PCI intensities remained steady between $1.5^{\circ} \mathrm{C}$ and $2{ }^{\circ} \mathrm{C}$ throughout the day.

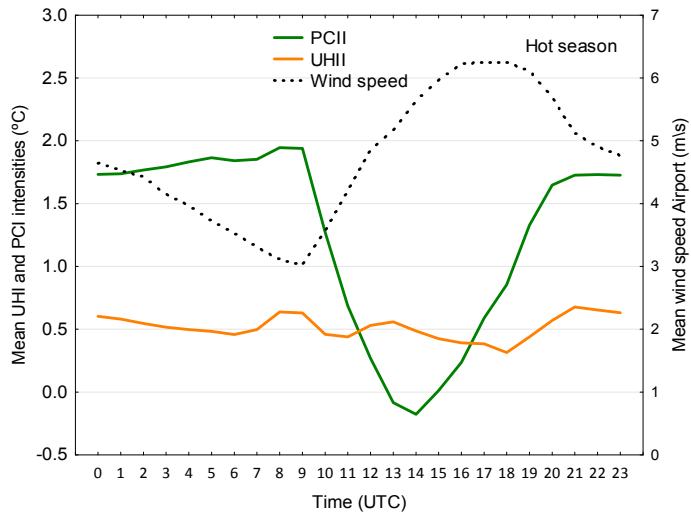

(a)

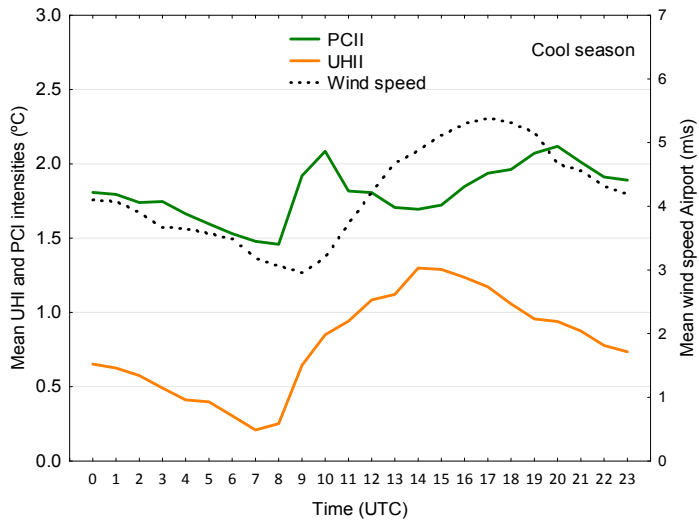

(b)

Figure 9. Daytime variation of the average Urban Heat Island (UHI) and Park Cool Island (PCI) intensities and average wind speeds in the (a) hot season and (b) cool season in the 2014-2016 period. 
The stratification of the wind speed and the correspondent values of average UHI intensities can be seen in Table 2. The highest wind speeds concentered in the $4<\mathrm{x} \leq 6 \mathrm{~ms}^{-1}$ class with $44.5 \%$ of frequencies, followed by $2<x \leq 4 \mathrm{~ms}^{-1}$ with $22 \%$, and $6<x \leq 8 \mathrm{~ms}^{-1}$ with $21 \%$. In this wind speed classes, UHI intensity remained steady about $0.6^{\circ} \mathrm{C}$ and PCI intensity varied between 1.5 and $1.7^{\circ} \mathrm{C}$. The $0<x \leq 2 \mathrm{~ms}^{-1}$ class represented only $5.7 \%$ of the observations, which corresponds to 905 of the occurrences in a total of 15,640 cases analyzed. Analyzing this class is particularly important, since it represents, according to the specialized literature, part of the anticyclonic conditions responsible for maximizing UHI intensities. In this class, the average UHI intensity steadied at $0.6{ }^{\circ} \mathrm{C}$ and PCI intensity at $1.6^{\circ} \mathrm{C}$. The $8<\mathrm{x} \leq 10 \mathrm{~ms}^{-1}$ and $\mathrm{x}>10 \mathrm{~ms}^{-1}$ classes $(0-2 \%)$ registered the lowest UHI and $\mathrm{PCI}$ intensities, both at about $0.3^{\circ} \mathrm{C}$.

Table 2. Relative frequency of wind speed stratification and respective averages UHI and PCI intensities in the 2014-2016 period.

\begin{tabular}{ccccc}
\hline & Wind Speed & & \multicolumn{2}{c}{ Mean Intensity $\left({ }^{\circ} \mathbf{C}\right)$} \\
\hline Class $\left(\mathbf{m s}^{-\mathbf{1}}\right)$ & No. of Observations & Frequency $\mathbf{( \% )}$ & UHI & PCI \\
\hline $0<x \leq 2$ & 905 & 5.7 & 0.7 & 1.6 \\
$2<x \leq 4$ & 3468 & 22 & 0.6 & 1.7 \\
$4<x \leq 6$ & 7000 & 44.5 & 0.6 & 1.5 \\
$6<x \leq 8$ & 3308 & 21 & 0.6 & 1.1 \\
$8<x \leq 10$ & 310 & 2 & 0.4 & 0.6 \\
$>10$ & 4 & 0 & 0.3 & 0.3 \\
Cases not analyzed & 645 & 4 & - & - \\
Total & 15,640 & 100 & - & - \\
\hline
\end{tabular}

Figure 10 plotted the distribution of UHI and PCI intensities in association with wind speeds, showing the major (positive and negative) temperature difference between the range from 3 to $8 \mathrm{~ms}^{-1}$ with the intensities declined from $8 \mathrm{~ms}^{-1}$ to UHI and from $9 \mathrm{~ms}^{-1}$ to PCI.

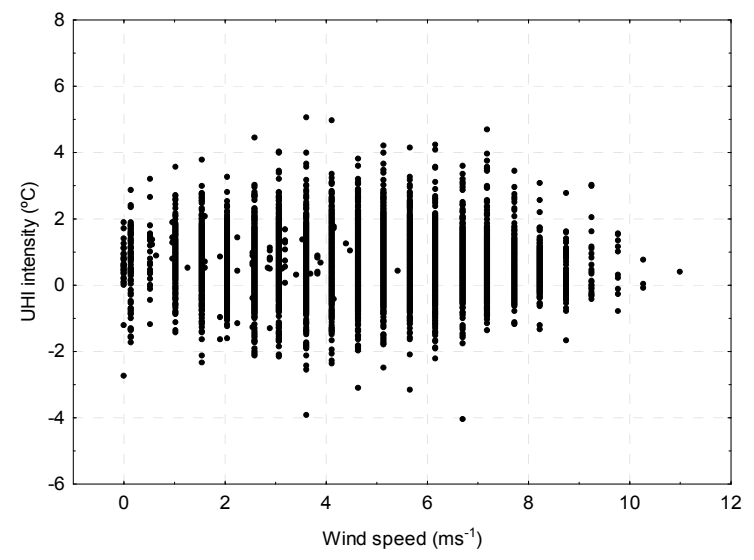

(a)

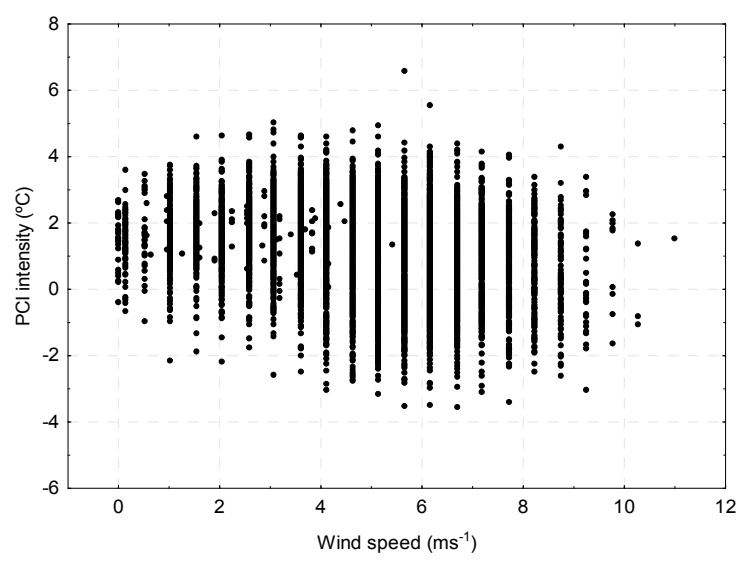

(b)

Figure 10. Scatterplot showing the distribution of the association between Urban Heat Island (UHI) (a) and Park Cool Island (PCI) (b) intensities and wind speed in the 2014-2016 period.

\subsection{The Relationship Between UHII and PCII and Sky Conditions}

The relative frequencies shown in Table 3 indicate that the most active sky conditions in Aracaju were markedly partly cloudy ( $76 \%$ or 11,942 cases) followed by very cloudy $(13.5 \%)$ and clear sky $(4.5 \%)$. In partly cloudy category, UHII and PCII of around $0.6{ }^{\circ} \mathrm{C}$ and $1.4{ }^{\circ} \mathrm{C}$ were registered, respectively. The overcast sky category $(0 \%)$ recorded the lowest UHII at $0.2 \%$ and the highest PCII at $2{ }^{\circ} \mathrm{C}$. Regarding the distribution of UHI and PCI intensities in association with sky conditions, Figure 11 shows the 
major (positive and negative) temperature difference between the center of the city and peri-urban areas, as well as those relations to urban park that occurred on the partly cloudy and very cloudy categories. In partly cloudy, the maximum extreme of UHI and PCI intensities of $5.5^{\circ} \mathrm{C}$ and $6.6^{\circ} \mathrm{C}$ were observed, respectively, while in very cloudy, the minimum extreme of UHI less than $-3{ }^{\circ} \mathrm{C}$ was registered.

Table 3. Relative frequency of sky conditions' stratification and respective UHI and PCI average intensities in the 2014-2016 period.

\begin{tabular}{ccccc}
\hline & Sky Conditions & & \multicolumn{2}{c}{ Mean Intensity $\left({ }^{\circ} \mathbf{C}\right)$} \\
\hline Categories & No. of Observations & Frequency (\%) & UHI & PCI \\
\hline Clear sky & 726 & 4.5 & 0.5 & 1.2 \\
Partly cloudy & 11,942 & 76 & 0.6 & 1.4 \\
Very cloudy & 1630 & 13.5 & 0.7 & 1.5 \\
Overcast sky & 4 & 0 & 0.2 & 2.0 \\
Cases not analyzed & 908 & 6 & - & - \\
Total & 15,640 & 100 & - & - \\
\hline
\end{tabular}

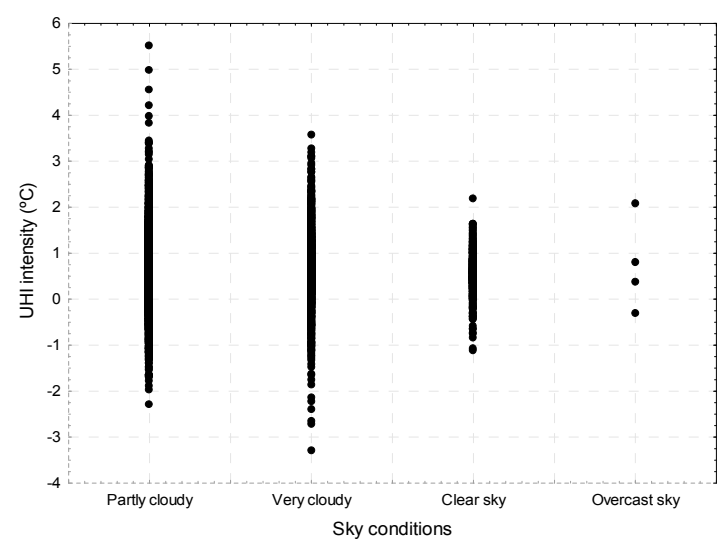

(a)

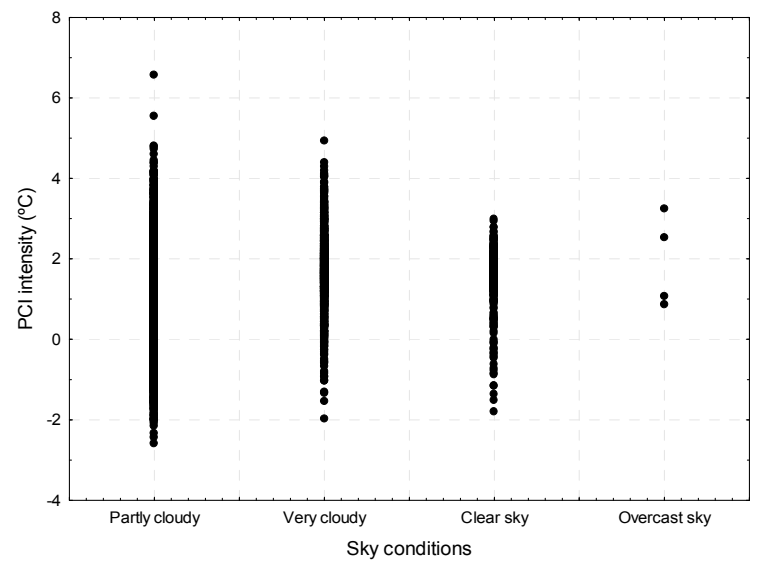

(b)

Figure 11. Scatterplot showing the distribution of the association between Urban Heat Island (UHI) (a) and Park Cool Island (PCI) (b) intensities and sky conditions in the 2014-2016 period.

\section{Discussion}

Recent results confirm the tendency found in previous studies [10-12]: in Aracaju local climates are indeed influenced by urban morphology, natural ventilation, and proximity to water bodies. The combination of these features forms three well-defined local climates in Aracaju. The first local climate can be seen in the Jardins urban station, which is characterized by relatively high and compact urban densities. As a result, there was the average increase of $1.5^{\circ} \mathrm{C}$ in the nighttime and the maximum of $2{ }^{\circ} \mathrm{C}$ at the early hours of the day. The second local climate observed is represented by Parque da Cidade urban station, where the green space's influence or cooling effect in the temperature drop (up to $2{ }^{\circ} \mathrm{C}$ ) during the night and the beginning of the morning was confirmed. However, the cooling effect was not significant during the whole afternoon, which may be explained by the average wind speed rise at that moment. The other local climate is the José Sarney Beach location, where the influence of the water bodies and natural ventilation is more significant. This local climate is characterized by a decrease of the high temperatures mainly during the afternoon period.

These local climates are significantly defined by microclimatic influences so that the great urban space diversity can create a myriad of local climates. Such common conception cannot be understood 
with the UHI intensity notion adopted in this study, which was defined fundamentally by the average temperature differences between measuring sites in the center of the city and in peri-urban areas.

Overall, in Aracaju, the UHI has proven to be more intense during the cool season than in the hot season. The results have shown that during cool afternoons UHI intensity averages increased with a peak of $1.3^{\circ} \mathrm{C}$ at 15:00 caused by the overall average wind speed decrease (maximum of $5.2 \mathrm{~ms}^{-1}$ ) compared to the hot season (maximum of $6 \mathrm{~ms}^{-1}$ ), whereas in this season the average daily UHI intensity was of about $0.5^{\circ} \mathrm{C}$, which is considered a case of the near-absence of UHI. Therefore, the low intensity UHI class (up to $2{ }^{\circ} \mathrm{C}$ ) was largely the most predominant one in more than $87 \%$ of the analyzed cases. In contrast to the UHI, the so-called 'urban cool island' (UCI) phenomenon of up to $-4{ }^{\circ} \mathrm{C}$ was expressively observed, i.e., where the air temperatures in peri-urban areas were warmer than those of the center of the city (negative values in Figure 10a). The UCI phenomenon in Aracaju occurred with significant intensities in the 2014-2016 period, which may be explained by the small thermal storage capacity and little anthropogenic heat [32], sea breeze and backdoor cold fronts, enabling the cold air to penetrate much further inland [33] or associated with the rapid heating in the peri-urban area when it receives solar radiation during the day [34].

The low daytime variation of the UHI in Aracaju may be affected beyond small-sized urban areas by changes to local climate factors, such as proximity to the sea, windiness, and cloudiness. The area where Aracaju is located implies that the great thermal ocean capacity softens and regulates temperature variations throughout the day due to the great quantity of water vapor that proceeds from the ocean. This has an impact on the low annual typical thermal amplitude of the region near the equator (latitude $10^{\circ}$ ). The wind systems in these locations are characterized by the persistence of trade winds (on average with $4.7 \mathrm{~ms}^{-1}$ ) throughout the year, which, by nature, highlights the important role played by the heat stored in the urban morphology, which actually explains the low intensities in many tropical cities, as reported by Oke et al. [35] and Arnfield [36]. Overall, the small-size city or relative low urban densities (seen through SVF values) facilitate the entry for air circulation within the city, which allows the heating stored to dissipate more easily from the urban canyons, creating, in most cases, a low thermal difference between the urban area and the peri-urban area.

In fact, the windiness and cloudiness can affect UHI development and intensity. It has been argued before that the urban/peri-urban temperature difference tends to become more noticeable under 'ideal' weather conditions (low wind speed and clear sky). However, in Aracaju, these weather conditions represented $10 \%$ of the frequencies analyzed and did not present the highest UHI intensities. Most UHI intensities occurred on wind speeds from 2 to $7 \mathrm{~ms}^{-1}$ with the maximum values $\left(5.5^{\circ} \mathrm{C}\right)$ within the 2 to $6 \mathrm{~ms}^{-1}$ range (44\%). The results of this study are in accordance with the ones observed in Lisbon, where Lopes et al. [3] and Alcoforado et al. [4] reported that the highest frequencies of UHI intensities—including the strongest ones $\left(6^{\circ} \mathrm{C}\right)$ - took place at wind speeds between 2 and $6 \mathrm{~ms}^{-1}$, due to the importance of the shelter effect in the measurement sites from Northern winds.

Oke and Hannell [6] suggested a critical wind speed in which UHI intensities distort and annul themselves. In Aracaju, the critical wind speed was near $8 \mathrm{~ms}^{-1}$, a value that is in consonance with the values seen in other cities with a different geographical context, especially those on the coast that have registered a tendency for the highest values of critical wind speed, as shown in Table 4 . Furthermore, UHI in Aracaju developed more under the partly cloudy (76\%) and very cloudy (13.5\%) sky conditions, which supposes some presence of clouds (from 1 to 4 octas) most of the day. Thus, the long-term monitoring revealed that UHI intensities in Aracaju did not develop prominently in the 'classic' weather conditions, which suggests that the urban/peri-urban temperature difference can also be more highlighted in other conditions. This finding is critical since the classic conditions have been broadly guiding the research on UHI. 
Table 4. Comparison between other cities regarding critical wind speed values in which UHI is distorted and annulled.

\begin{tabular}{ccc}
\hline Critical Wind Speed $\left(\mathbf{m s}^{\mathbf{- 1}}\right)$ & City & Reference \\
\hline 11 & Busan & Kim and Baik [37] \\
10 & Bueno Aires & Camilloni and Barrucand [38] \\
9.4 & Daegu & Kim and Baik [37] \\
8 & Lisbon & Lopes et al. [3] \\
7.8 & Aracaju & This study \\
7 & Salamanca & Alonso et al. [39] \\
7 & Seoul & Kim and Baik [40] \\
6.4 & Daegreon & Kim and Baik [37] \\
\hline
\end{tabular}

The PCI phenomenon described by Oke [41] as the 'oasis effect' was observed in Aracaju. Results have shown that urban vegetation played an important role in the reduction of high air temperatures, which means that it can be considered as a potential measure to mitigate the thermal stress effects in the city. Unlike UHI, PCI was dynamic with significant seasonal and daily variations. Fortunately, the cooling effect produced by the green space (Parque da Cidade station) was visibly present during the analyzed period. For reference: more than 3700 of the total 15,640 cases in which the PCI intensity $\geq 2$ ${ }^{\circ} \mathrm{C}$ with the average daily maximum PCI intensity of $6.6^{\circ} \mathrm{C}$ were computed. Results also revealed that the average $\mathrm{PCI}$ intensity varied between $1.5^{\circ} \mathrm{C}$ and $2{ }^{\circ} \mathrm{C}$, which is consistent, to a certain extent, with the values of other studies, as shown in Table 5.

Table 5. Comparison between cities of the average PCI intensity according to the dimension of the urban park.

\begin{tabular}{cccc}
\hline PCI Intensity $\left({ }^{\circ} \mathbf{C}\right)$ & Park Size (Hectares) & City & Reference \\
\hline $2-3$ & 500 & Mexico city & Jauregui [23] \\
$1.3-2.7$ & 15 & Sacramento & Spronken-Smith and Oke [16] \\
$1.5-2$ & 93 & Aracaju & This study \\
1.7 & 24.2 & Seoul & Lee et al. [42] \\
1.6 & 0.24 & Lisbon & Oliveira et al. [17] \\
$1-1.5$ & 4.8 & Vancouver & Spronken-Smith and Oke [16] \\
$1-2$ & 0.24 & Kumamoto & Saito [43] \\
\hline
\end{tabular}

The low intensity PCI class (up to $2{ }^{\circ} \mathrm{C}$ ) of these cases was more predominant between 53 and $93 \%$ of cases, whereas the average intensity class (from $2{ }^{\circ} \mathrm{C}$ to $4{ }^{\circ} \mathrm{C}$ ) tended to increase during the cool season both in the daytime and the nighttime periods, representing $45 \%$ of the occurrences. Unfortunately, the low occurrence of the medium and strong intensities during the hot season was observed. In this study, one has to keep in mind that the stronger the PCI intensity is, the higher the temperature (surface and air) reduction in relation to the surrounding built area shall be.

Although the average PCI intensities remained steady between $1.5^{\circ} \mathrm{C}$ and $2{ }^{\circ} \mathrm{C}$ for several whole cool days, it was proved in this study that the green space is not always cooler than the central area, mostly during the hot days. This situation seen in Aracaju has been reported in other cities, e.g., Tel Aviv [21] and Mexico City [23]. In the Aracaju case, the reduction of the PCI during the hot afternoons period should be linked to a temperature rise significantly on Parque Cidade station (up to $30{ }^{\circ} \mathrm{C}$ at 15:00) which keeps the urban park warmer, as illustrated the Figure 5a and an increase in the average wind speed which keeps the central area of the city cooler, as illustrated the Figure 9a. In this situation, the temperature differences between these areas to decrease dramatically to the point that the PCI is annulled, including the observation of the $\mathrm{PCI}$ intensity of $-2.5{ }^{\circ} \mathrm{C}$. The measurements of the Parque da Cidade station, as well as the rest of the stations, may explain that fact, since these measurements were made to avoid the shadowing effect not only of buildings but also of trees and therefore all the sensors were exposed to solar radiation. In addition, the physical characteristics of the 
green space analyzed, such as surface and roughness, are related to the thermal heating verified, as those of the Potchter et al. [21] and Chang et al. [22] studies mentioned previously.

Just like the UHI, PCI intensities did not only develop in the aforementioned 'ideal' weather conditions, which goes against the findings of other studies (e.g., Upmanis et al. [20]) that point to the fact that the cooling effect is more noticeable in those conditions. The results of this study revealed that most PCI intensities (positive and negative values) concentered on winds speeds from 4 to $6 \mathrm{~ms}^{-1}$ and sky conditions that fall in the partly cloudy and very cloudy categories. This suggests that the cooling effect and the cooling winds from the sea can act together (or one compensates the other) to reduce high temperatures and, consequently, improve the bioclimatic comfort in the city.

\section{Conclusions}

With long-term monitoring, the UHI and PCI intensities in Aracaju city were assessed precisely. Based on the local climatological network, we know there are three well-defined local climates, which are influenced by urban densities, proximity to water bodies, and green spaces. Because of the network architecture, an appropriate assessment to measure UHI and PCI intensities was performed. Representativeness at the local scale through a group of urban stations with similar thermal characteristics $\left(\Delta \mathrm{Tu}_{\text {(group) }}\right)^{\left.-r_{\text {(group) }}\right)}$ was ensured, instead of considering values only through the comparison of one station in the urban area with another in the peri-urban area $\left(\Delta \mathrm{Tu}_{=u r b a n}-\mathrm{r}_{=\mathrm{rural}}\right)$.

This study strongly corroborates the notion that daily UHI and PCI intensities are inherent to local ventilation. The wind system (trade winds) is steady throughout the year and should be the critical factor for the apparently little dynamic nature of the UHI in the hot season and its higher intensity in the cool season. In the hot season, on average, UHI intensity of $0.5^{\circ} \mathrm{C}$ is nearly absent (including the UCI phenomenon), while the highest average $\mathrm{PCI}$ intensity $\left(2{ }^{\circ} \mathrm{C}\right)$ occurred with the lowest average speed wind $\left(1 \mathrm{~ms}^{-1}\right)$ in the morning. However, during the afternoon period PCI intensity declined abruptly up to $-0.2{ }^{\circ} \mathrm{C}$ when the wind speed increased up to $6 \mathrm{~ms}^{-1}$. Also, the significant temperature increase (maximum of $30^{\circ} \mathrm{C}$ ) on Parque Cidade station helped to explain the reduction of the $\mathrm{PCI}$ in that period. In the cool season, with the decrease of the average wind speeds up to $5.2 \mathrm{~ms}^{-1}$ and the decrease in temperature on Parque Cidade station (maximum of $27.5^{\circ} \mathrm{C}$ ), the PCI intensities remained steady between $1.5^{\circ} \mathrm{C}$ and $2{ }^{\circ} \mathrm{C}$ throughout the day, while the average UHI intensities increased with a peak at $1.3^{\circ} \mathrm{C}$. Furthermore, this study reported that most UHI and PCI intensities did not develop only in the so-called 'classic' weather conditions (light winds and clear sky), but actually the intensities of these phenomena were distributed regularly in conditions that were opposed to those, namely with winds from 4 to $6 \mathrm{~ms}^{-1}$ and the partly cloudy and very cloudy sky conditions categories.

We argue that consistent long-term monitoring in the cities is very important to provide more accurate climatic information about the UHI and PCI to be applied in urban planning properly, e.g., for the creation of thermally pleasant urban spaces.

Acknowledgments: This research was funded by CAPES-Foundation, Ministry of Education of Brazil, Brasília DF 70040-020, Brazil (process No. 1135-13-9).

Author Contributions: The authors contributed to all in this study.

Conflicts of Interest: The authors declare no conflict of interest.

\section{References}

1. Martin-Vide, J.; Sarricolea, P.; Moreno-García, M.C. On the definition of urban heat island intensity: The "rural" reference. Front. Earth Sci. 2015, 3, 1-6. [CrossRef]

2. Alcoforado, M.J. Planning Procedures Towards High Climatic Quality Cities: Example referring to Lisbon. Finisterra 2006, 82, 49-64. [CrossRef]

3. Lopes, A.; Alves, E.; Alcoforado, M.J.; Machete, R. Lisbon Urban Heat Island Updated: New Highlights about the Relationships between Thermal Patterns and Wind Regimes. Adv. Meteorol. 2013, 2013, 1-11. [CrossRef] 
4. Alcoforado, M.J.; Lopes, A.; Alves, E.D.L.; Canario, P. Lisbon Heat Island-Statistical Study $2004-2012$. Finisterra 2014, 98, 61-80. [CrossRef]

5. Morris, C.J.G.; Simmonds, I.; Plummer, N. Quantification of the Influences of Wind and Cloud on the Nocturnal Urban Heat Island of a Large City. J. Appl. Meteorol. 2001, 40, 169-182. [CrossRef]

6. Oke, T.R.; Maxwell, G.B. Urban heat island dynamics in Montreal and Vancouver. Atmos. Environ. 1975, 9 , 191-200. [CrossRef]

7. Rizwan, A.M.; Dennis, L.Y.C.; Liu, C. A review on the generation, determination and mitigation of Urban Heat Island. J. Environ. Sci. 2008, 20, 120-128. [CrossRef]

8. Oke, T. Initial Guidance to Obtain Representative Meteorological Observations at Urban Sites; IOM Report No. 81, WMO/TD. No. 1250; World Meteorological Organization: Geneva, Switzerland, 2006.

9. Alexander, P.; Mills, G. Local Climate Classification and Dublin's Urban Heat Island. Atmosphere 2014, 5, 755-774. [CrossRef]

10. Anjos, M.; Ganho, N.; de Araújo, H.M. The heat island and relative humidity in Aracaju-Sergipe (Brazil): intensity and behavior itra-daytime. Cad. Geogr. 2014, 33, 47-57. [CrossRef]

11. Anjos, M.; Ganho, N.; Araújo, H. Uma análise dos contrastes topoclimáticos no espaço urbano e periurbano de Aracajú (SE): Os campos térmicos e higrométricos. Rev. Bras. Climatol. 2013, 13, 298-318. [CrossRef]

12. Anjos, M. Ambiente urbano: Contrastes térmicos e higrométricos espaciais em Aracaju-Sergipe (Brasil). Master's thesis, University of Coimbra, Coimbra, Portugal, 2012.

13. Anjos, M.; Lopes, A.; Alves, E.D.L.; Lucena, A.J. Rede climatológica de mesoescala aplicada ao estudo da Ilha de Calor Urbano: o caso de Aracaju-SE. Caminhos Geogr. 2017, 18, 203-216. [CrossRef]

14. Stewart, I.D. A systematic review and scientific critique of methodology in modern urban heat island literature. Int. J. Climatol. 2011, 31, 200-217. [CrossRef]

15. Oke, T. The Need to Establish Protocols in Urban Heat Island Work. Paper Presented at the T.R. Oke Symposium \& Eighth Symposium on Urban Environment, Phoenix, AZ, USA, 11-15 January 2009; Available online: http:/ /ams.confex.com/ams/89annual/techprogram/paper_150552.htm. (accessed on 12 March 2017).

16. Spronken-Smith, R.A.; Oke, T.R. The thermal regime of urban parks in two cities with different summer climates. Int. J. Remote Sens. 1998, 19, 2085-2104. [CrossRef]

17. Oliveira, S.; Andrade, H.; Vaz, T. The cooling effect of green spaces as a contribution to the mitigation of urban heat: A case study in Lisbon. Build. Environ. 2011, 46, 2186-2194. [CrossRef]

18. De Abreu-Harbich, L.V.; Labaki, L.C.; Matzarakis, A. Effect of tree planting design and tree species on human thermal comfort in the tropics. Landsc. Urban Plan. 2015, 138, 99-109. [CrossRef]

19. Doick, K.; Hutchings, T. Air Temperature Regulation by Urban Trees and Green Infrastructure; Research Note 12; Forestry Commission: Edinburgh, UK, 2013.

20. Upmanis, H.; Chen, D. Influence of geographical factors and meteorological variables on nocturnal urban-park temperature differences-A case study of summer 1995 in Göteborg, Sweden. Clim. Res. 1999, 13, 125-139. [CrossRef]

21. Potchter, O.; Cohen, P.; Bitan, A. Climatic behavior of various urban parks during hot and humid summer in the mediterranean city of Tel Aviv, Israel. Int. J. Climatol. 2006, 26, 1695-1711. [CrossRef]

22. Chang, C.-R.; Li, M.-H.; Chang, S.-D. A preliminary study on the local cool-island intensity of Taipei city parks. Landsc. Urban Plan. 2007, 80, 386-395. [CrossRef]

23. Jauregui, E. Influence of a large urban park on temperature and convective precipitation in a tropical city. Energy Build. 1990, 15, 457-463. [CrossRef]

24. Muller, C.L.; Chapman, L.; Grimmond, C.S.B.; Young, D.T.; Cai, X.M. Toward a standardized metadata protocol for urban meteorological networks. Bull. Am. Meteorol. Soc. 2013, 94, 1161-1185. [CrossRef]

25. Stewart, I.D.; Oke, T.R. Local climate zones for urban temperature studies. Bull. Am. Meteorol. Soc. 2012, 93, 1879-1900. [CrossRef]

26. Mills, G.; Bechtel, B.; Ching, J.; See, L.; Feddema, J.; Foley, M.; Alexander, P.; Connor, M.O. An Introduction to the WUDAPT project. In Proceedings of the ICUC9-9th International Conference on Urban Climate, Toulouse, France, 20-24 July 2015.

27. Bechtel, B.; Alexander, P.; Böhner, J.; Ching, J.; Conrad, O.; Feddema, J.; Mills, G.; See, L.; Stewart, I. Mapping Local Climate Zones for a Worldwide Database of the Form and Function of Cities. ISPRS Int. J. Geo-Inf. 2015, 4, 199-219. [CrossRef] 
28. Anjos, M.; Lopes, A. Urban Heat Island first statistical assessment based on an mesoscale climatological network in Aracaju/Brazil. In Proceedings of the 9th International Conference on Urban Climate, Toulouse, France, 20-24 July 2015.

29. Lin, T.P. Thermal perception, adaptation and attendance in a public square in hot and humid regions. Build. Environ. 2009, 44, 2017-2026. [CrossRef]

30. Lindberg, F.; Grimmond, C.S.B. Continuous sky view factor maps from high resolution urban digital elevation models. Clim. Res. 2010, 42, 177-183. [CrossRef]

31. García, F.F. Manual de Climatología Aplicada: Clima, Medio Ambiente y Planificación; Síntesis: Madrid, Spain, 1995. (In Spanish)

32. Yang, X.; Li, Y.; Luo, Z.; Chan, P.W. The urban cool island phenomenon in a high-rise high-density city and its mechanisms. Int. J. Climatol. 2017, 37, 890-904. [CrossRef]

33. Gedzelman, S.D.; Austin, S.; Cermak, R.; Stefano, N.; Partridge, S. Mesoscale aspects of the Urban Heat Island around New York City. Theor. Appl. Climatol. 2003, 42, 29-42.

34. Figuerola, P.I.; Mazzeo, N.A. Urban-rural temperature differences in Buenos Aires. Int. J. Climatol. 1998, 18, 1709-1723. [CrossRef]

35. Oke, T.R.; Zeuner, G.; Jauregui, E. The surface energy balance in Mexico City. Atmos. Environ. Part B Urban Atmos. 1992, 26, 433-444. [CrossRef]

36. Arnfield, A.J. Two decades of urban climate research: A review of turbulence, exchanges of energy and water, and the urban heat island. Int. J. Climatol. 2003, 23, 1-26. [CrossRef]

37. Kim, Y.H.; Baik, J.J. Daily maximum urban heat island intensity in large cities of Korea. Theor. Appl. Climatol. 2004, 79, 151-164. [CrossRef]

38. Camilloni, I.; Barrucand, M. Temporal variability of the Buenos Aires, Argentina, urban heat island. Theor. Appl. Climatol. 2012, 107, 47-58. [CrossRef]

39. Alonso, M.; Fidalgo, M.; Labajo, J. The urban heat island in Salamanca (Spain) and its relationship to meteorological parameters. Clim. Res. 2007, 34, 39-46. [CrossRef]

40. Kim, Y.-H.; Baik, J.-J. Maximum Urban Heat Island Intensity in Seoul. J. Appl. Meteorol. 2002, 41, 651-659. [CrossRef]

41. Oke, T. Boundary Layer Climates, 2nd ed.; Routledge: London, UK, 1987.

42. Lee, S.-H.; Lee, K.-S.; Jin, W.-C.; Song, H.-K. Effect of an urban park on air temperature differences in a central business district area. Landsc. Ecol. Eng. 2009, 5, 183-191. [CrossRef]

43. Saito, I.; Ishihara, O.; Katayama, T. Study of the effect of green areas on the thermal environment in an urban area. Energy Build. 1990, 15, 493-498. [CrossRef] 